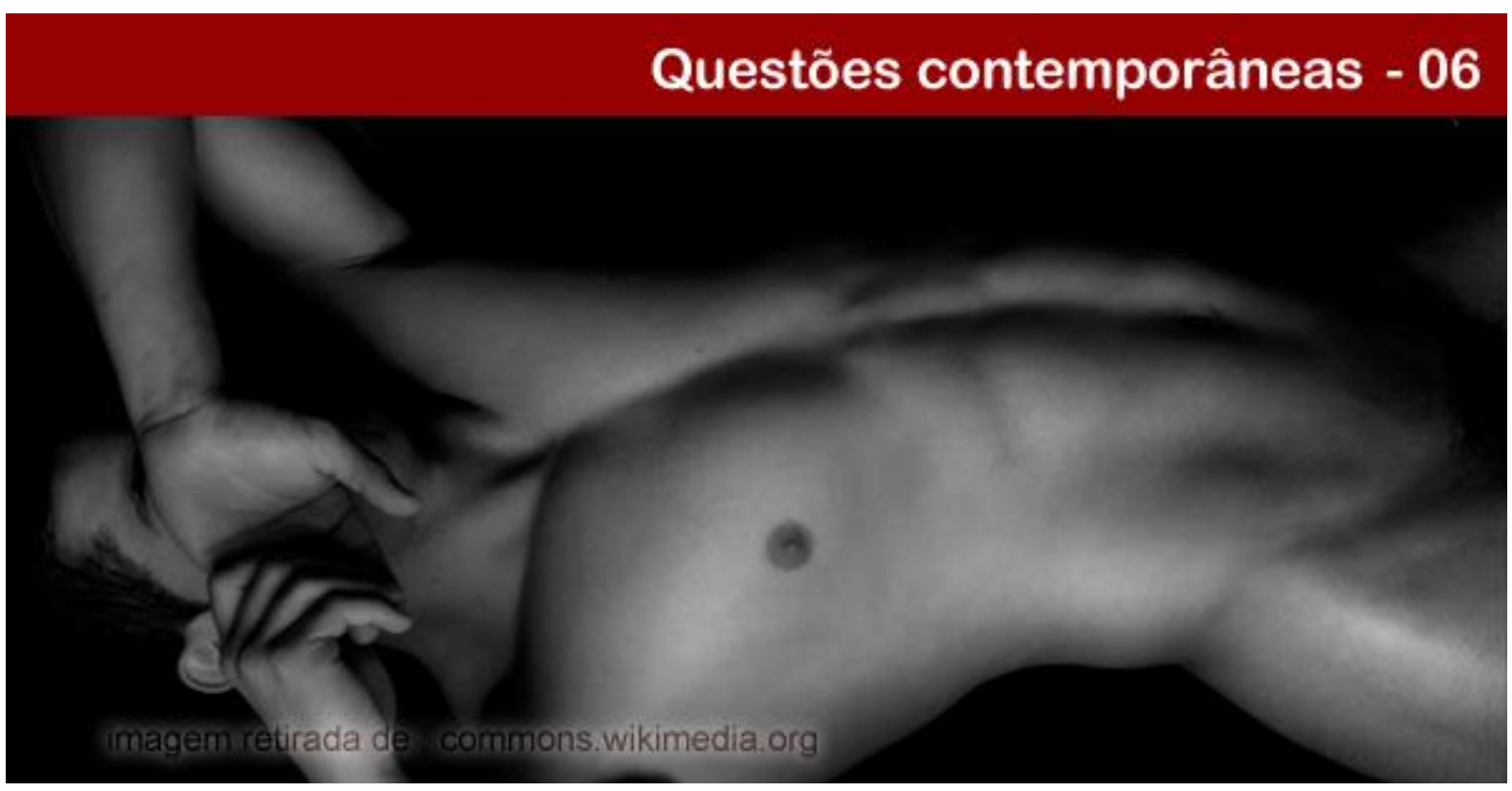

\title{
O CORPO-PORNÔ: REFLEXÕES SOBRE SEUS DESDOBRAMENTOS SOCIAIS E CULTURAIS
}

\author{
Júnior Ratts \\ Escritor, Bacharel e Mestre em Comunicação pela Universidade Federal do Ceará (UFC). E-mail: \\ jr.ratts@gmail.com.
}

Resumo: Neste trabalho, pretende-se refletir, baseado nas teses sobre corpo, imagem, identidade e pornografia desenvolvidas por David Le Breton, Michel Maffesolli, Norval Baitelo Jr., Susan Sontag, dentre outros, sobre o que é o corpo-pornô e quais os seus desdobramentos sociais e culturais para a construção do Si Mesmo dos atores e telespectadores. O ponto de partida do trabalho é a análise das falas contidas na entrevista aplicada ao casal de atores pornôs brasileiros Diego Lauzen e Wagner Vittoria.

Palavras-chave: Pornô. Corpo. Subjetividade.

\section{THE BODY-PORN: REFLECTIONS ON ITS SOCIAL AND CULTURAL DEVELOPMENTS}

Abstract: In this work, it is intended to reflect, based on theories about body, image, identity and pornography developed by David Le Breton, Michel Maffesolli, Norval Baitelo Jr., Susan Sontag, among others, about what body-porn is and what their social and cultural developments for the construction of the Self of actors and viewers. The starting point of the work is the analysis of the statements contained in the interview applied to double Brazilian porn actors Diego Lauzen and Wagner Vittoria.

Keywords: Porn. Body. Subjectivity.

\section{Introdução}

Vê-se o pornô, não se olha o pornô: é o que se tem constatado no dia a dia na conversa com pessoas que apreciam este gênero cinematográfico e que nele não observam mais nada para além de corpos desnudos a praticar um sexo explícito e espetacularizado. Por isso mesmo, esta pesquisa procura, cada vez mais, entender o que há por trás das imagens do 
pornô: menos suas denotações, e mais suas conotações. Desta forma, busca-se humanizar o pornô e, por consequência, os corpos envolvidos em suas redes de agenciamentos.

Ainda sob a lógica da humanização do pornográfico, neste trabalho, pretende-se tratar das seguintes questões: o que é o corpo-pornô, o que o constitui e como sua construção afeta os sujeitos contemporâneos; de que forma este corpo da pornografia reflete a realidade generalizada do corpo na contemporaneidade no que se refere ao seu materializar e consequente construção do Eu em comunhão com as imagens midiáticas, com a Imagem como instituição e com o olhar do Outro; de quais maneiras a exposição detalhada do corpopornô em seus excessos está ligada a uma ponte deste corpo em relação ao Si Mesmo e ao telespectador, interferindo na constituição do self de todos os envolvidos na construção da imagem pornográfica. E ainda: como acreditar que, para além das imagens explícitas do sexo (e antes delas), seja possível existir uma relação de fidelidade e gratidão entre os sujeitos do pornô e destes com os consumidores de pornografia.

Tenciona-se responder estas questões a partir do relato da história de vida de um casal de atores brasileiros que atuam na produtora internacional de filmes pornôs gay Kristen Bjorn, a saber, Diego Lauzen e Wagner Vittoria. A escolha dos dois sujeitos se deu em virtude do casal - em seu curto período de atuação na indústria do sexo - ter se tornado uma referência nacional e internacional no que diz respeito à uma atuação de qualidade; o que, no pornô, significa vivenciar com a maior fidedignidade possível todos os signos próprios das tramas midiáticas sexuais.

Com base no relato de vida desses dois indivíduos (obtido através de uma série de entrevistas aplicadas por e-mail) e recorrendo às teses sobre pornografia desenvolvidas por Abreu (1996), Díaz-Benítez (2009), Baudrillard (1992) e Sontag (1987), às teorias sobre corpo apresentadas por Le Breton (2012) e aos trabalhos acerca da relação entre sujeito e imagem desenvolvidos por Baitello (2005) e Maffesoli (1995 e 2005), dentre outras referências, serão apresentados alguns pressupostos sobre identidade, sociedade, corpo, imagem e tecnologia a fim de compreender melhor de que maneira as imagens de uma forma geral e as imagens de si em particular funcionam como uma ferramenta de religare social (MAFESSOLI, 1995) e de que forma este fenômeno sociocultural aliado aos processos atuais de pornorização de si contribui para a construção de uma cultura da individualidade que se dá através de um reconhecimento das potencialidades do corpo.

\section{POLÊM!CA | Revista Eletronica da Ueij}




\section{Da solidariedade e fidelidade no pornô}

O casal brasileiro Diego Lauzen e Wagner Vittoria são dois grandes ícones internacionais do pornô gay. À época da entrevista, entre fevereiro e março de 2014, o casal estava junto há quase três anos e atuava na indústria pornográfica há um ano e meio. Segundo Wagner, neste período, eles já haviam atuado juntos e com outros atores em 35 cenas, uma média de duas cenas por mês.

A vida na indústria da pornografia não foi iniciada por necessidade financeira ou por um desejo pessoal (dois dos principais motivos que geralmente levam os indivíduos a adentrar neste ramo), mas, de acordo com Vittoria, por pura "artimanha" do destino. O casal estava de férias em Barcelona quando a produtora Tim Tales enviou um convite para o perfil deles no site Gay Rome, convidando-os para realizar uma cena de sexo que seria postada para visualização no período apenas de uma semana. De acordo com Wagner, o casal achou o convite interessante e aceitou fazer o vídeo para guardar como recordação, porém a repercussão na internet foi tamanha que, uma semana depois, eles foram convidados a assinar um contrato de exclusividade com a Kristen Bjorn, uma das mais renomadas produtoras de filmes pornôs gays do mundo. Além do convite inusitado, a vaidade também foi um dos fatores preponderantes para a adesão dos dois às tramas do pornô. "Acredito que, pra aceitar uma proposta na pornografia, com certeza a vaidade conta muito. Saber que as pessoas gostam e seguem o seu trabalho aumenta muito a sua autoestima", revelou Wagner.

Por isso e por outros motivos, a vida como atores pornôs, segundo Wagner, só lhes trouxe benefícios: trabalharam muito em vários lugares lindos do mundo e conheceram pessoas maravilhosas, por exemplo. O autoconhecimento do próprio corpo é outro fator apontado como positivo. "O pornô me fez ter mais cuidado com o meu corpo e como saber usá-lo na frente das câmeras, saber qual o meu lado melhor para ser filmado, essas coisas.”. Fora isso, o casal apresentou a boa relação entre eles e os fãs como um motivo primordial para permanecer na carreira. "O carinho enorme que recebemos das pessoas que acompanham nosso trabalho paga tudo", confessou Diego.

Ainda de acordo com eles, apesar da profissão exigir obviamente o contato sexual com outros homens, o casal leva uma vida supernormal, que inclui longas jornadas na academia, cuidar da casa, sair para o cinema, jantar fora e organizar festas com os amigos (alguns deles

\section{POLÊM!CA | Revista Eletronica da Ueij}


atores com os quais contracenam na Kristen Bjorn). Além dos filmes, Diego e Wagner trabalham em boates como go go boys, escort e fazem apresentações de sexo ao vivo.

Quando o assunto família foi abordado, Diego afirmou que sua família sabe e apoia sua profissão de ator pornô. Já Wagner disse que apenas alguns primos têm conhecimento de sua profissão, visto que ele tem um filho de 13 anos e não considera o momento oportuno para o jovem tomar conhecimento sobre o ofício do pai. Ao mesmo tempo em que se mostrou preocupado, Wagner também confessou que tinha orgulho do seu trabalho e, por isso, não teria grandes problemas se a família inteira descobrisse sua profissão.

$\mathrm{Na}$ entrevista, o que mais chamou a atenção foi a relação de amor e fidelidade criada pelo casal em meio ao exercício de uma profissão que exigia deles, como dito, a prática sexual com outros sujeitos do sexo masculino (o casal nunca fez filmes com mulheres ou indivíduos trans). Quando questionados sobre a necessidade de fazer sexo com outras pessoas, Wagner deixou bem claro que isso era algo preciso, afinal, segundo ele, "35 cenas só com nós dois se tornaria chato para quem assiste". Ainda sobre o afeto, nas palavras do casal, o que o pornô trouxe de melhor para o relacionamento foi o aumento da confiança um no outro. E isso se dá dentro de um esquema de racionalização do corpo e do desejo. "Dividimos amor e sexo, nos amamos e nos respeitamos muito. Enquanto gravamos, fazemos sexo e nos divertimos, damos um ao outro a liberdade de aproveitar e se divertir", afirmou o casal. Essa diversão, contudo, não é sempre recorrente e, às vezes, fazer sexo se torna apenas um trabalho, confessou Wagner. No entanto, afirmou, a performance sexual do casal na frente das telas possui a mesma intensidade do sexo realizado na intimidade, tendo sempre em vista a preocupação em transmitir para o telespectador um prazer, de fato, real.

Figura - 1: Casal Wagner Vittoria (à esquerda) e Diego Luazen (à direita)

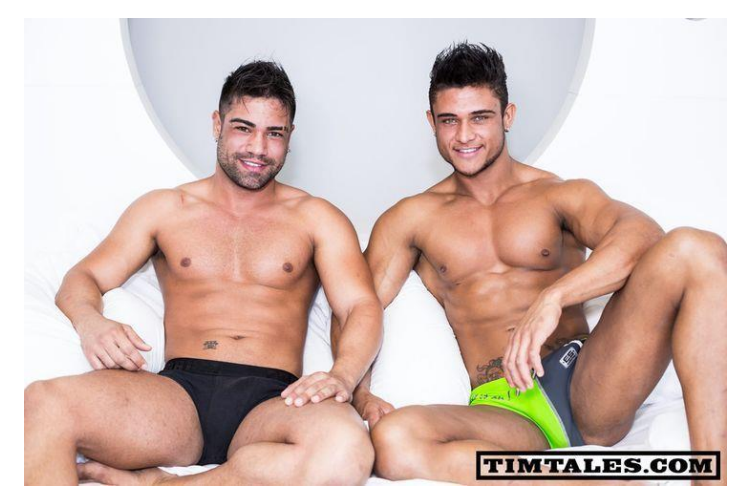

Fonte: Timtales.com.

\section{POLÊM!CA | Revista Eletronica da Uerj}




\section{Corpo-pornô: pensando o corpo que faz corpos}

A partir das falas dos dois atores, serão abordadas algumas questões acerca da realidade do corpo na contemporaneidade no que se refere ao seu materializar (e consequente construção do Eu) em comunhão com a mídia e com o olhar do Outro.

Tradicionalmente, o sujeito social é educado a ter dois corpos (um individual e um coletivo) e, ao mesmo tempo, não possuir corpo algum ${ }^{1}$; a ser mais um signo de Si do que o Si Mesmo. E este signo se faz de marcas, contornos, gestos e adornos que denotam relações de poder, que traduzem a forma como o olhar panóptico ${ }^{2}$ da sociedade se faz presente na forma de ser e estar no mundo. Os profissionais da pornografia, por meio da sedução e do sexo que praticam (apesar de sua teatralidade), evocam justamente a condição de um corpo que existe e que pode se multiplicar em vários signos que operam em revelia ao poder da tradição. É claro que o panoptismo não deixa de existir nestes cenários ${ }^{3}$ e que os corpos também são inclinados a se materializar em conformidade com interesses que lhes são superiores e que se manifestam de forma direta ou indireta (esses interesses estão relacionados à economia, à luta de classes, à raça, etc). O que então diferencia estes corpos dos demais que permeiam o cotidiano é a consciência do uso tático da máscara, da brincadeira que fazem com o Si Mesmo e de como sua materialização depende de um desempenho cênico aliado ao uso das tecnologias disponíveis. Foi a "brincadeira de férias" que deu início à carreira de Wagner e Diego e foi a satisfação corporal em ver-se por meio da mídia o que os manteve na indústria. A realidade materializada de seus corpos lhes possibilitou, assim, materializar outros tantos desejos (fazer viagens, ter fãs, etc).

\footnotetext{
${ }^{1}$ De acordo com Le Breton, "a proximidade da experiência corporal e dos signos que a manifestam aos outros, a partilha comum dos ritos que constituem a sociabilidade são as condições que tornam possíveis a comunicação, a constante transmissão do sentido no interior de uma sociedade dada. Mas paradoxalmente, por meio da conivência assim estabelecida com o corpo espelhando outrem, a familiaridade do sujeito com a simbolização de seus próprios usos corporais ao longo de sua vida cotidiana, parece que o corpo apaga-se, que ele desaparece do campo da consciência, diluído no quase automatismo dos ritos diários" (LE BRETON, 2012, p. 191 e 192).

${ }^{2}$ O panóptico era, de acordo com Foucault (1997), um dos mecanismos oitocentistas de controle corporal e que operava em várias instituições (entre elas, a escola, os hospitais, o exército, os conventos, as fábricas, etc.) a fim de manter o corpo sob a condição de máquina utilitária em uma nova realidade industrial e capitalista. Nos dias atuais, pode-se observar essa manifestação panóptica atuando através dos meios de comunicação, dentre outras esferas da sociedade.

${ }^{3}$ Ler DÍAZ-BENÍTEZ, María Elvira. Retratos de uma orgia: a efervescência do sexo no pornô. In: DÍAZBENÍTEZ, María Elvira \& FÍGARI, Carlos Eduardo (Org.). Prazeres dissidentes. Rio de Janeiro: Garamond, 2009.
} 
Fora isso, o corpo exposto permitiu a criação de um elo forte entre os dois e deles para com os consumidores de suas imagens. "O maior elogio pra um ator pornô é quando alguém te escreve e diz que se masturbou muito olhando a sua cena”, confessou Wagner. Como se vê, o espelho da mídia reforça as capacidades de vidência e visibilidade do corpo (MERLEAUPONTY, 2002) e assim possibilita uma reformulação do self dos indivíduos ${ }^{4}$ envolvidos nas tramas do pornô (sejam atores ou telespectadores). O sexo na pornografia deixa, dessa forma, de ser signo de perversão e se transforma em signo de solidariedade e autoconstrução de si a partir do momento em que as práticas sexuais de outrem - em sua condição de significante sugerem significados diferentes sobre a constituição do desejo.

Este fenômeno revela como o corpo, no pornô, “é a fonte de comunicação, parecendo conter todos os discursos [...]" (ABREU, 1996, p. 160). O corpo é o cenário da experiêncialimite onde se joga tudo (ABREU, Idem). Dessa maneira, o jogo de olhares entre telespectador e personagens que caracteriza a construção da imagem cinematográfica, na pornografia, terá o corpo como principal vetor. O corpo no pornô, pode-se dizer, é todo o olho do espectador; é feito do olhar do espectador que sobre ele se deixa construir ao construí-lo. O telespectador que se masturba ao visualizar o corpo de Wagner constrói/revitaliza o corpo pornorizado de Wagner e seu próprio corpo entregue na trama erótica-sexual. Por isso, é esse olhar que pode conduzir o espectador a uma percepção nova ou renovada da condição do Outro e de sua própria condição como sujeito desejante e desejável. Complemento esta hipótese com a tese de Edward Carpenter segundo o qual o sexo "vem primeiro, e as mãos, os olhos, a boca, o cérebro vêm depois; das entranhas irradia-se o conhecimento do eu" (CARPENTER apud GIDDENS, 1993, p. 175). Em suma, o corpo faz corpos e este é um dos princípios do corpo-pornô: produzir uma consciência complexa sobre si a partir de uma revisão do sexo como ferramenta de enunciação performática, e não mais como última necessidade a ser realizada dentro de medidas "saudáveis de comportamento" ou por meio de práticas consideradas clandestinas.

\footnotetext{
${ }^{4}$ Essa ação midiática de mostrar o Outro (e consequentemente o mundo em que esse Outro habita) está diretamente relacionada à construção do $e u$, visto que, conforme aponta Thompson (1998, p. 181): “o processo de formação do self é cada vez mais alimentado por materiais simbólicos mediados". [...] "o desenvolvimento midiático não somente enriquece e transforma o processo de formação do self, ele também produz um novo tipo de intimidade que não existia antes". Essa nova forma de intimidade se dá principalmente por meio daquilo que o autor intitula de quase-interação mediada, a qual não tem o grau de reciprocidade interpessoal de outras formas de interação como a mediada ou a face a face, mas mesmo assim "cria um certo tipo de situação social na qual os indivíduos se ligam uns aos outros num processo de comunicação” (Idem, p. 80).
}

\section{POLÊM!CA | Revista Eletronica da Ueij}


O sexo revisado funciona, então, como uma ferramenta tática na construção do sujeito como indivíduo em uma sociedade de indivíduos, pois o diferencia baseado em sua autoconstrução (um sujeito se descobre um corpo de prazer ao visualizar a imagem de um outro sujeito que se descobre fonte de prazer para o Outro) e ambos se assemelham (tornamse indivíduos únicos e iguais através da consciência de si e das utopias adquiridas por meio das imagens midiáticas do sexo). Ou seja, tornam-se indivíduos a partir de um fazer por si mesmo ao apropriar-se dos recursos que dispõem: o corpo, o sexo e a mídia (os três envolvidos na produção ilimitada de imagens de si).

O corpo-pornô - a partir dos laços de solidariedade que desenvolve do corpo para o próprio corpo e deste para outros corpos (dos outros atores, dos telespectadores) - determina um lugar diferenciado para o sexo. Levando em consideração que, nesta pesquisa, trata-se mais da imagem do corpo pornorizado do que do corpo propriamente dito, vale pensar que a teoria da Iconofagia de Baitello, a qual traduz um processo de consumo da imagem pelo indivíduo ao ponto deste se tornar uma imagem a ser consumida, aplica-se muito bem ao fenômeno referido. Contudo, os laços de solidariedade que são estabelecidos entre os sujeitos que constroem a imagem do pornô (nesse caso, atores e telespectadores) direcionam o trabalho para uma perspectiva mais humanizada sobre esta imagem nos termos apresentados pela tese de Maffesoli: ou seja, a imagem do corpo sexualizado como elemento constituinte de um narcisismo coletivo, o qual "enfatiza a estética, pois promove estilos particulares, um modo de vida, uma ideologia, uma maneira de vestir, um comportamento sexual, enfim, tudo o que é da ordem da paixão partilhada.” (MAFFESOLI, 2005, p. 23).

Mais se dirá sobre a relação entre as imagens do pornô e as teorias desses dois autores a fim de fazer compreensível a fascinação pela pornografia na atualidade. Porém, agora, outro autor será evocado para que se possa avaliar como a experiência-limite do corpo pornorizado reflete questões importantes para o corpo contemporâneo.

\section{Questionando Baudrillard: de um pornô esvaziado de sedução a uma sedução provocada por um hiper-pornô}

Baudrillard em Da Sedução desenvolve uma tese nada positiva sobre o pornô. Segundo o autor, o excesso do corpo e do sexo disseminaram a sedução no gênero. Diz ele: “O pornô é a quadrifonia do sexo. Ele acrescenta uma terceira e quarta pista ao ato sexual. 
Reina a alucinação do detalhe" (1992, p. 39). Apesar dessa visão pessimista sobre a pornografia, o próprio Baudrillard apresenta, em outra obra, a sexualidade como uma hipótese (2004, p. 26), no que diz respeito a uma impossibilidade em defini-la dentro de padrões rigorosos de conceitualização. Neste sentido, teorizo que o pornô não esgota a sedução nem elimina o imaginário acerca do sexo em virtude da exposição eminente dos corpos em seus detalhes. Pelo contrário, a exposição detalhada do corpo em seus excessos atribui ao corpo uma dimensão "mágica" cuja função é criar uma ponte entre este corpo desnudo de enigmas e seu Si Mesmo e, ainda, entre ele e quem o enxerga através das mídias.

Um conto da escritora britânica Virgínia Woolf (2005) descreve bem este fenômeno. Em "A mulher no espelho", a autora relata que somente conseguia captar os enigmas e signos de sua amiga Isabela quando esta se colocava diante do espelho. Durante toda a narrativa, Virgínia é tomada por assombros causados pela explosão da imagem do corpo no espelho, as quais, através de uma estética do espetáculo, refletiam as dimensões "reais" do corpo: "De imediato o espelho começou a verter sobre ela uma luz que parecia pregá-la; que parecia um ácido que corrói o não-essencial e o superficial e deixa apenas a verdade. Era um espetáculo encantador. Tudo imanava de Isabela - nuvens, vestidos, cesto, diamante [...]" (WOOLF, 2005, p. 98). A autora demonstra, assim, que existe, no espelho, um duplo que engrandece para o bem e para o mal, pois deforma e apresenta o real, tornando-o superior ao revelá-lo como objeto de admiração e verdade.

Merleau-Ponty (2002) também tece uma tese sobre essa dimensão fantástica do espelho. De acordo com o filósofo,

\begin{abstract}
Como todos os outros objetos técnicos, como os utensílios, como os signos, o espelho surgiu no circuito aberto do corpo vidente ao corpo visível. Toda a técnica é "técnica do corpo". Ela figura e amplia a estrutura metafísica da nossa carne. O espelho aparece porque eu sou vidente-visível, porque há uma reflexibilidade do sensível, que ele traduz e redobra. Através dele, o meu exterior completa-se, tudo o que eu tenho de mais secreto passa nesta face, neste ser plano e fechado, de que já meu reflexo na água me fazia suspeitar (MERLEU-PONTY, 2002, p. 30).
\end{abstract}

Acompanhando o raciocínio de Woolf e Ponty e tendo em mente que a mídia é um espelho $^{5}$ a refletir uma realidade dos corpos midiatizados, a qual cria um envolvimento

\footnotetext{
${ }^{5}$ De acordo com Sodré, o “"espelho' midiático não é simples cópia, reprodução ou reflexo, porque implica uma forma nova de vida, com um novo espaço e modo de interpelação coletiva dos indivíduos, portanto, outros parâmetros para a constituição das identidades pessoais" (SODRÉ, 2002, p. 23).
}

\title{
POLÊM!CA | Revista Eletronica da Ueij
}


mítico-erótico-religioso ${ }^{6}$ com o telespectador, gerando com isso novas configurações identitárias, chega-se às seguintes conclusões sobre os corpos no pornô: 1) O corpo hipervisível, a um só tempo, reafirma e descontrói o imaginário em torno do sexo ao revelar informações arbitrárias que, por sua repetição, assumem o status de verdades sobre os gêneros e as sexualidades a partir da realidade espetacularizada das práticas sexuais; 2) A alucinação do detalhe acompanha a lógica de Sontag $^{7}$, ou seja, a hiper-exposição faz parte da essência do gênero pornográfico, sem reduzi-lo em comparação a outros gêneros cinematográficos; e mais importante: 3) O corpo detalhado restaura para os participantes da cena e para o telespectador a existência de um corpo e de uma eroticidade masculinas sempre escondidas por uma moral vitoriana ${ }^{8}$.

Assim, se o corpo só existe em seu excesso (LE BRETON, 2012), o pornô em sua excessividade seria a plataforma de visualização e, mais ainda, de problematização das formas como o corpo contemporâneo, finalmente visível em cada um de seus pedaços, vive em uma relação paradoxal entre o conflito e o prazer de mostrar-se (conflito que está diretamente ligado a sua constituição física e subjetiva). Seguindo essa lógica, o teatro do sexo no pornô reafirma e põe em xeque ${ }^{9}$ o teatro do sexo na vida real, revelando condições, ao mesmo tempo, impossíveis de serem realizadas (tendo em conta a performance espetacular dos atores e atrizes) e completamente possíveis de realização (visto que estes movimentos são realizados por pessoas normais). O que quer dizer que o pornô funciona como uma gramática do corpo que o ensina a materializar-se e a sentir-se corpo ao permitir que ele acione novos imaginários

\footnotetext{
${ }^{6}$ Muniz Sodré diz que “a relação do corpo humano, frágil e precário, com o 'corpo' tecnológico é ao mesmo tempo erótica e religiosa" (SODRÉ, 2005, p. 78).

${ }^{7}$ Quando Sontag (1967) argumenta sobre a desqualificação da pornografia como gênero literário em vista das proezas sexuais e do esvaziamento psicossocial dos personagens descritas nas obras e da paisagem irreal e ahistórica na qual os enredos decorrem. Apesar de teorizar sobre literatura, os argumentos de Sontag podem muito bem ser aplicados ao cinema. Diz ela sobre o gênero pornográfico e suas especificidades: "Tais negações do tempo social, do espaço e da personalidade reais, concretos e tridimensionais (assim como as ampliações 'fantásticas' da energia humana) são precisamente os ingredientes de um outro gênero de literatura, fundado num modo diverso de consciência" (SONTAG, 1967, p. 12). Levando a tese de Sontag para o cinema, podemos perceber o pornô como mais um dos vários gêneros cinematográficos existentes, o qual possui características próprias, dentre elas o hiper-realismo, que não o diminui frente aos outros gêneros, apenas o diferencia do drama, do terror, etc.

${ }^{8}$ De acordo com Boodakian, a exibição do corpo nu masculino heterossexual sofre sempre a ameaça da punição. Em contrapartida, "em sua grande maioria, homens gays não compartilham o desejo masculino heterossexual de manter o corpo nu masculino fora do campo de observação. Isso se dá particularmente porque a maioria dos gays não teme a perda de poder implicada na participação do circuito periférico, uma vez que em muitas culturas, eles já habitam esses círculos por outros motivos" (2006, p. 147).

${ }^{9}$ Conforme afirma Diaz-Benítez, a pornografia "conserva e recria regras em um período que se acredita desregrado" (2009, p. 594).
} 
e novas práticas de prazer a partir das imagens de um sexo espetacularizado. Imaginários estes que se transformam em memória e hábitos de autoconhecimento corporal. Como afirma Bozon:

\begin{abstract}
Parece que nada de sexual poderia acontecer, sequer uma masturbação solitária, se não existissem produções sociais e mentais, assumindo a forma de cenários, em que atos, relações e significados da sexualidade se encontrem inscritos e organizados em histórias. Esses cenários funcionam como guias de orientação ou de leitura, permitindo aos indivíduos situar-se e atribuir um sentido sexual às sensações, situações, palavras e estados corporais (BOZON, 2004, p. 129).
\end{abstract}

As palavras de Bozon ganham reforço na declaração de Wagner Vittoria: "O pornô te estimula a provar coisas novas, posições diferentes, diferentes coisas para aquecer o sexo. Tudo que faço na cama aprendi assistindo filmes pornôs e acredito que com quase todos é assim". Neste contexto, o pornô funciona como um script sexual (BOZON, 2004) que permite um religare do sujeito com seu próprio corpo e com o corpo do outro. Essa consciência da conexão pornográfica se faz visível, por exemplo, no momento em que o ator Wagner diz sempre ter recusado fazer filmes heterossexuais, pois, por sua condição de homossexual assumido, realizar tais filmes "seria sem prazer e o público veria isso". Esta afirmação confere ao pornô e à sua hiper-realidade três aspectos: 1) Ele é um espaço de afirmação de identidade de gênero e de sexo; 2) É um espaço no qual o prazer pode ser exercido de forma real mesmo através de um sexo espetacularizado; e 3) Há uma consciência dos atores em relação à importância do sexo como aspecto integrante de sua subjetividade e da subjetividade do Outro.

Em outras palavras, o pornô com suas carnes à mostra constrói sujeitos à medida que trabalha com o hipercorpo e com o hipersexo, tornando-os familiares aos diversos indivíduos (atores e telespectadores) por sua condição de sistemas abstratos. De acordo com Giddens (1991, p. 115), "os sistemas abstratos propiciam uma boa dose de segurança na vida cotidiana que estava ausente nas ordens pré-modernas". Para o sociólogo, o reconhecimento da importância dos mecanismos que constituem os sistemas abstratos se dá toda vez que alguém aciona qualquer tipo de tecnologia disponível no cotidiano, como um saque no banco ou o envio de uma carta. Ainda segundo Giddens

com o desenvolvimento dos sistemas abstratos, a confiança em princípios impessoais, bem como em outros anônimos, torna-se indispensável à existência social. A confiança impessoalizada deste tipo é discrepante da confiança básica. Há 
uma forte necessidade psicológica de achar outros em quem confiar, mas as conexões pessoais institucionalmente organizadas estão faltando em relação às situações sociais pré-modernas (GIDDENS, 1991, p. 122, grifo nosso).

Isso quer dizer que, quando o sujeito contemporâneo liga o reprodutor de DVD ou acessa um vídeo pornô na internet, está, na verdade, a procurar por esse Outro em quem confiar, ainda que ele esteja envolvido em uma narrativa sexual explícita. Sendo assim, é no sexo do Outro que o indivíduo deseja restabelecer algum tipo de (auto) confiança perdida, algum elemento constituinte do self que se perdeu em meio ao "caos" contemporâneo. Neste caso, o corpo midiatizado do pornô teria muito mais a oferecer do que conteúdo sensual/erótico com fins à excitação sexual. Assim, o sujeito constrói seu mundo com aquilo que está à disposição e, dentre estes materiais constituintes da realidade, está o pornô e, em suas redes, os corpos hiperexpostos que, com sua sedução, reconecta o indivíduo ao seu corpo imaginado, tornando-o real e concreto por meio do prazer.

\section{Este alheio corpo tão meu - Considerações (nunca) finais}

Conforme apresentado em outra seção deste trabalho, faz-se agora necessário o desenvolvimento de algumas considerações sobre como a relação corpo-imagem, com base nas teses de Michel Maffesoli e Norval Baitello Jr, estão imbricadas na simbiose entre o telespectador e os sujeitos do pornô. Apesar de o autor de o Mistério da Conjunção se apresentar geralmente como um entusiasta da imagem em contraposição ao segundo autor cuja teoria enxerga na profusão imagética o caos de uma sociedade perdida diante do espelho (seja ele qual for), as teses dos dois filósofos precisam ser aqui apresentadas para que a pesquisa possa dar continuidade às suas hipóteses acerca da importância do corpo-pornô para o indivíduo (homem ou mulher) contemporâneo.

De acordo com Baitello, o sujeito se encontra, como foi mencionado, na Era da Iconofagia, na qual a relação sujeito e imagem se dá por meio de um processo em que as imagens, em um primeiro momento, necessitam dos indivíduos para existir e fazerem-se consumíveis; concluída esta fase, as imagens passam a consumir os sujeitos que, em seu processo de consumo imagético, foram transformados em imagens, novas ou semelhantes àquelas sobre as quais se detinham. Há duas características interessantes neste processo. A primeira se refere à tese de que esta nova sociedade, sustentada sob os pilares da "serial imagery society", não mais vive de pessoas, feitas de corpos e vínculos, mas de uma 
sequência de imagens infindável, sempre idênticas (2005, p. 51, grifo nosso). O segundo aspecto aponta para um consumo imagético cuja adesão das imagens se dá por uma "função biombo" em contraposição à "função janela". Ou seja, "ao invés de remeter ao mundo e às coisas, elas passam a bloquear seu acesso, remetendo apenas ao repertório ou repositório das próprias imagens" (Idem, p. 54). Por fim, o autor chega à conclusão de que, em meio a essa demanda crescente de produção de imagens em série, a corporeidade insiste e resiste.

Se para Baitello a sociedade bombardeada por imagem determinou a consumação dos corpos e consequentemente dos vínculos estabelecidos por estes, para Maffesoli o consumo voraz das imagens permite que os laços coletivos prevaleçam sobre a individualidade (MAFFESOLI, 1995, p. 145). O filósofo apresenta, além do narcisismo coletivo, uma nova ética que sustenta essa realidade - a ética da estética - cujo sentido é "vibrar por meio de imagens comuns, gozar, nem que seja de maneira relativa, do mundo tal como ele é" e confirmar com isso a existência de "um cimento, um vínculo social que se estabelece a partir daquilo que, à primeira vista, pode ser considerado frívolo" (MAFFESOLI, 1995, p. 146).

O corpo-pornô se enquadra neste contexto de "futilidades" úteis a um religare de um indivíduo ao Outro e a si próprio. A fala do ator Wagner revela isso quando ele diz que a preocupação com a performance advém tanto de uma necessidade por um cuidado de si como por uma vontade de construir um ambiente de prazer "real" para o Outro que o assiste em sua performance sexual. O depoimento de Bill Margold, historiador pornô, ex-ator, agente e produtor, valida ainda mais essa religação com o eu e com o social que se dá a partir da tríade corpo, imagem, consumo: “Cada um de nós, não importa o quão insignificante pensamos ser, queremos ser reconhecidos em um momento de nossas vidas. (...) O que oferecemos na indústria pornô por um curto e glorioso momento é imortalidade, validação e credibilidade".

Estas características fazem com que se perceba que, de fato, o campo da indústria pornográfica é um terreno de transitoriedade fugaz cuja base está na multiplicação de corpossignos constituídos em um contexto mercadológico que faz com que o corpo varie entre a glória e o vácuo ${ }^{10}$. Quer dizer, o corpo-pornô pode ser vislumbrado, na contemporaneidade, a partir da condição de entidade na qual se deposita os anseios e do qual se retira elementos

\footnotetext{
${ }^{10}$ Ser "imagem" (signo icônico) pública significa tornar-se interpretante vivo ou núcleo politópico de uma determinada conjuntura de valores, significa tornar-se 'médium'. Mas significa também se realizar como forma acabada e abstrata da relação humana mediada pelo mercado, ou seja, existir como indivíduo 'irreal', mero suporte para signos que se dispõem a representar uma realidade instituída exclusivamente como mercadoria (SODRÉ, 2002, p. 38).
}

\section{POLÊM!CA | Revista Eletronica da Ueij}


para a construção do self, que se dá em conformidade com um desejo que, ao mesmo tempo em que pertence a cada um, pode ser também vislumbrado como um produto forjado pela cultura. Por estar implicado em relações de poder que reproduzem questões políticas, econômicas, raciais, etc, este corpo segue uma padronização de beleza e comportamento que, de alguma forma, produz um recorte na visão geral de mundo, estereotipando a realidade (função biombo) e fazendo dos sujeitos que visualizam e que fazem parte da indústria do pornô imagens sexuais de si mesmo (segundo estágio da Era da Iconofagia) que se põem a consumir enquanto se consomem. Contudo, se é possível pensar dessa forma, é viável também pensar no corpo-pornô - a partir da validação e credibilidade que a indústria lhe confere - como um "corpo de luz"11, o que o liga ao mito do Puer Aeternus ${ }^{12}$ e com isso abre um espaço de novas possibilidades de ser e estar no mundo no que se refere ao universo sexual e erótico (função janela).

Em outras palavras, o corpo (neste caso, o corpo-pornô) que proclama, por vezes, a conversão do indivíduo aos ideais do mercado, refaz, através das suas imagens, a unidade do corpo (corpo stricto sensu, produto industrializado, produto comercializado, comunidade local) e do espírito (qualitativo, sentido da beleza, desinteresse caricativo, prazer pelo sensível, acentuação do próximo e da vizinhança) ao "realizar o jogo da tradição figurativa, que é enfatizar a dimensão hedonista, irônica e estética da existência” (MAFFESOLI, 1995, 137). O corpo-pornô, em meio a esse contexto, pode ser entendido como um produto cultural que, como tal, é construído pela cultura ao passo que constrói uma cultura particular de olhar (o mundo, o self, os corpos, etc) a partir de um ponto de vista sexual-erótico-midiático. Sendo assim, a sua hiperexposição tem a ver com uma necessidade que é construída pela indústria, mas também por aqueles que desejam, por força do imaginário, ver a alucinação da carne. Alucinação que contribui para a construção de uma cultura do olhar, mas também da individualidade, a qual, mesmo estando sujeita a uma coletividade normativa, permite que o indivíduo (tendo a imagem como ferramenta) gere para si pequenos espaços de

\footnotetext{
11 Maffesoli atribui esse termo aos corpos individuais que “são adornados, 'emperiquitados', que são construídos, que são cosmetizados em excesso, a sala de musculação, o salão de cabeleireiro e as modas de vestir estão aí para prová-lo, esses corpos se espiritualizam, 'angelizam-se' (1995, p. 135);

${ }^{12}$ Esse mito, de acordo com Maffesoli, é "ingênuo e impudente, puro e perverso, possui todas as características da criança que porque está próxima da natureza anima, brinca com seu corpo, pode colocá-lo em espetáculo, mas, porque está inserido na civilização, vai fazer esse corpo falar, conscientizá-lo, dar a ele um espírito" (1995, p. 136).
}

\section{POLÊM!CA | Revista Eletronica da Ueij}


problematização, construção, desconstrução, subversão e redescoberta de seus desejos e habilidades no campo daquilo que é considerado pornô-erótico-sexual.

\section{Referências}

ABREU, Nuno Cesar. O olhar pornô: A representação do obsceno no cinema e no vídeo. Campinas: Mercado de Letras, 1996.

BAITELLO, Norval Jr. Ensaios de Comunicação e Cultura. São Paulo: Hacker Editores, 2005.

BAUDRILLARD, Jean. Da Sedução. Campinas, São Paulo: Papirus, 1992.

Telemorfose. Rio de Janeiro: Mauad, 2004.

BOODAKINA, Florence Dee. Despindo os códigos: gênero, relativismo cultural e o corpo nu. In: GARCIA, Wilton (org.). Corpo e subjetividade: estudos contemporâneos. São Paulo: Factash Editora, 2006.

BOZON, Michel. Sociologia da sexualidade. Rio de Janeiro: Ed. FGV, 2004.

DÍAZ-BENÍTEZ, María Elvira. Retratos de uma orgia: a efervescência do sexo no pornô. In: DÍAZ-BENÍTEZ, María Elvira \& FÍGARI, Carlos Eduardo (Org.). Prazeres dissidentes. Rio de Janeiro: Garamond, 2009.

GIDDENS, Anthony. As conseqüências da modernidade. São Paulo: UNESP, 1991.

. A transformação da intimidade: sexualidade, amor e erotismo nas sociedades modernas. São Paulo: Editora Unesp, 1993.

LE BRETON, David. Antropologia do corpo e modernidade. Petrópolis: Editora Vozes, 2012.

MAFFESOLI, Michel. A contemplação do mundo. Porto Alegre: Artes e Ofícios Ed., 1995.

O mistério da conjunção: ensaios sobre comunicação, corpo e socialidade. Porto Alegre: Sulina, 2005.

MERLEAU-PONTY, Maurice. O olho e o espírito. Lisboa: Vega, 2002.

SODRÉ, Muniz. Antropológica do espelho: uma teoria da comunicação linear e em rede. $2^{\mathrm{a}}$ ed. Petrópolis: Ed. Vozes, 2006.

SONTAG, Susan. A imaginação pornográfica. In: A vontade radical. Rio de Janeiro: Cia. das Letras, 1987.

THOMPSON, John B. A mídia e a modernidade: uma teoria social da mídia. Petrópolis: Vozes, 1998.

WOOLF, Virgínia. Contos Completos. São Paulo: Editora Cosac Naify, 2005.

Recebido em: 19/06/2015.

Aceito em: 08/10/2015.

POLÊM!CA | Revista Eletronica da verj

Rua São Francisco Xavier, 524, $2^{\circ}$ andar - BL D, sl 2025 - Maracanã

Tels.: +55212334- $0888 / 0887$

http://www.labore.uerj.br/ - laboreuerj@yahoo.com.br 